Village, Andrew ORCID:

https://orcid.org/0000-0002-2174-8822 and Muskett, Judith A. (2017) Flagships in a sea of unbelief? Christian affiliation around big church buildings in England. Journal of Contemporary Religion, 32 (3). pp. 479-493.

Downloaded from: http://ray.yorksj.ac.uk/id/eprint/1756/

The version presented here may differ from the published version or version of record. If you intend to cite from the work you are advised to consult the publisher's version: http://www.tandfonline.com/doi/full/10.1080/13537903.2017.1362891

Research at York St John (RaY) is an institutional repository. It supports the principles of open access by making the research outputs of the University available in digital form. Copyright of the items stored in RaY reside with the authors and/or other copyright owners. Users may access full text items free of charge, and may download a copy for private study or non-commercial research. For further reuse terms, see licence terms governing individual outputs. Institutional Repository Policy Statement

\title{
RaY
}

Research at the University of York St John

For more information please contact RaY at ray@yorksj.ac.uk 
Running Head: Christian affiliation around churches

Flagships in a sea of unbelief?

Christian affiliation around big church buildings in England

\author{
Andrew Village \\ York St John University, UK \\ Judith A. Muskett \\ York St John University, UK
}

Author note. Correspondence concerning this article should be addressed to Professor Andrew Village, Theology \& Religious Studies, York St John University, Lord Mayor’s Walk, York YO31 7EX. UK. Email: a.village@yorksj.ac.uk

Word count: 6068 


\title{
Flagships in a sea of unbelief? Christian affiliation around big church buildings in England
}

\begin{abstract}
Census data has prompted research on why there is so much local variation in religious identity. This study uses the 2011 UK National Census key statistics aggregated by electoral wards to investigate whether the presence of an important church building (a 'flagship' cathedral or cathedral-like parish/abbey church) correlates with higher Christian affiliation than would be expected if there were no such church building nearby. Using all 6,712 English wards within $30 \mathrm{~km}$ of a large church, those within $3 \mathrm{~km}$ had about 5-7\% fewer selfidentified Christians than those further away. However, after controlling for social demography, wards closest to large churches had around 1\% more Christian affiliates than expected. Greater than expected levels of affiliation persisted when the analysis was restricted to buildings outside urban conurbations, or to just Anglican or just Roman Catholic cathedrals. Reasons for this 'proximity' effect are discussed, including the possibility that the sheer physical presence of such a building may heighten the chance of individuals selfidentifying as Christian.

[163 words]
\end{abstract}

Keywords: cathedrals, Census, Christian affiliation, Greater Churches, mission, vicarious religion. 


\section{Flagships in a sea of unbelief? Christian affiliation around big church buildings in England}

\section{Introduction}

In 2001 and 2011 the UK National Census included a voluntary question about religious affiliation (Weller; Field). Despite discussions prior to 2001 on whether or not to include more nuanced questions about attendance and denomination, the final question had a single category for Christian affiliation (Southworth). Analyses showed that in 2001 72\% of the population self-identified as Christian (Office for National Statistics, Focus), and in 2011 this figure was 59\% (Office for National Statistics “Religion”). Given the generally low attendance at Christian worship in the UK, these results sparked a series of investigations as to why Christian affiliation was so high and why there was so much local variation in religious identity. Voas and Bruce argued that the unexpectedly high level of affiliation in 2001 was due in part to the placement and wording of the question, and in part to anxiety about national and cultural identity. Others have cast doubt on the utility of the overall figures, notably non-religious groups such as the National Secular Society, who argue that most people who tick the 'Christian' box in the census are not religious in any meaningful sense (Porteous Wood quoted in Southworth 85, MORI). Despite these caveats about the overall level and meaning of Christian affiliation, the question has proved useful in identifying changes over time (Voas "Religious Census") and how it is distributed across different groups (Statistics).

Voas and McAndrew studied variations between English wards in 2001, focusing on the prevalence of 'non-religion' (which ranged between 1.9\% and 42.4\%) (41). They found that certain geographical areas (for example, Brighton, parts of Bristol, and Norwich) were distinctive even when controlling for age, sex and ethnicity. In trying to solve this puzzle, 
Voas and McAndrew pointed to various drivers, such as the local economy, the presence of immigrant communities (possibly encouraging the white British to self-identify as Christian, as “a marker of cultural and ethnic identity”) and “diffusion processes” (42); and they speculated that "area-level religious affiliation is likely to be affected by the presence of particular places of worship” (43). Their ‘spatial lag model’ (taking into account similarities between neighbouring areas) recognized that an important place of worship might impact equally upon an area and its neighbours. However, their analysis did not probe the ward data in such a way as to enable the testing of their proposition that particular places of worship (however defined) had a bearing upon the likelihood of local residents self-identifying as Christian.

The present study seeks to address the research question raised by Voas and McAndrew’s work; and, on the basis of English ward data from the most recent Census (2011), to determine whether the presence of a significant church building correlates with Christian affiliation. The analysis responds not only to the work of Voas and McAndrew, but also to Day's call, in the light of Davie's theorizing on vicarious religion (see in particular "Vicarious Religion” 25-6), for further exploration of the way churches retain symbolic importance for the public. One explanation of a 'proximity effect' is that large church buildings might, by their sheer physical presence, exert some influence on the likelihood of someone identifying themselves as 'Christian' rather than 'no religion'. Such a rather 'ethereal' effect is likely to be very difficult to detect, so the aim of the present study was to use a large sample of buildings and the largest possible sample of people, that is, the National Census. If any effect exists, it should be detectable by there being higher levels of affiliation near buildings than further away.

There may be many reasons why affiliation to a particular religion is higher nearer to a building used for worship by that religion. The most obvious would be that buildings are 
located specially to serve an already religious population, as is likely to be the case in Britain for buildings serving recent immigrant populations (mosques serving Muslim communities, temples serving Sikh or Hindu communities etc.). This would happen if immigrant settlement is geographically uneven, and places of worship are created to meet local needs. In these cases it is very likely that affiliation will be higher closer to the building than further away. The situation for large Christian buildings in England is very different. The historical links between Christian settlement and the creation of these buildings, if such links ever existed at all, have long since been overtaken by shifts in population and the declining levels of Christian affiliation. Even when churches were built to serve the shifting populations resulting from the Industrial Revolution, they may not necessarily have been located specifically to serve particularly Christian areas (an exception might be the location of Roman Catholic churches to serve Catholic immigrants in places such as Liverpool or Glasgow).

A second reason why there might be more Christian affiliates near to large church buildings is that they attract people to live there. The churches may be in beautiful, historic parts of towns and cities that attract particular sorts of people who have the desire and means to live nearby and are, for some reason, more likely to be Christians. The association could be indirect, reflecting a link between purely social or aesthetic reasons for living in wards near large churches and a greater likelihood that such people would tend to identify with Christianity rather than any other religion or no religion. If cathedrals, for example, are near historic universities and university staff were more likely to affiliate and live near the university then an association might be detectable. The association might also be direct if people chose to live near a large church mainly because they wanted to worship there (or were working there) and living nearby made attendance easier (or the journey to work shorter). 
A third reason why there might be more Christian affiliates near to large buildings is that these institutions are successful in mission to those who live nearby. People who settle nearby may be no more likely to affiliate than the population generally, but over time if they stay in the area they are likely to be drawn to the faith espoused by the institution that the building represents, and therefore become affiliates and perhaps worshippers. This would suggest that most worshippers at large churches live fairly close to the building, and have come to affiliate to Christianity because of the direct action of church people.

A fourth reason why there might be more Christian affiliates near to large buildings is that the "overwhelming physicality" of the building (Anderson 97) acts in some sort of symbolic way (Shearlock) to encourage identification with the religion it represents. In this case, when asked in surveys such as the Census, people may choose to identify with the faith not because they attend the place of worship, but because they feel an attachment to the building (see, for example, Danziger, Tilby; Walpole) or it exerts some power over them (Wharton). Large churches such as cathedrals can certainly dominate the landscape in some towns and cities (Anderson 90; Martikainen 128; Minton 68): Durham, Guildford and Lincoln are prime examples; and there is survey evidence that cathedrals are regarded as 'beacons of faith' (Theos and the Grubb Institute 17), that people 'get a sense of the sacred' from the building (18) and that cathedrals reach out beyond those who are part of the Church of England (25).

Deciding between these possibilities would require detailed surveys of large samples of people living in the vicinity of large church buildings, far more extensive than those carried out to date. An initial step is to see if there is any empirical evidence that Christian affiliation is actually spatially related to the presence of large buildings. Are people living near to buildings like cathedrals more or less likely to affiliate to Christianity than those who live further away? 


\section{Research question}

The Census religion question does not ask for affiliation beyond major religions (e.g. to the level of Christian denominations) and does not ask about attendance, so it is not possible to infer anything about why a person might or might not affiliate to Christianity, nor what that means in terms of attendance at worship. The aim of this paper is therefore to make an initial examination to see if any 'proximity effect' is discernible in the 2011 Census data for England. If it is, then there may be justification for future studies to find out why it exists. The hypothesis tested is that, after allowing for social-demographic variations, there will be a higher likelihood of someone living near a large church choosing to answer the religion question ‘Christian’ rather than 'no religion' compared with someone living further away.

\section{Method}

\section{Census Wards}

The Census geography allows religious affiliation and other demographic information to be assigned to electoral wards and electoral divisions. Wards with fewer than 1,000 people or 400 households are merged in the Census output files (in 2011 these accounted for less than one percent of the 9,505 Census wards and Census electoral divisions), so that key statistics are reported for 'census merged wards'. Such wards cover the whole of the UK and in 2011 there were 7,678 in England. Postcodes published in the National Postcode Directory (NPCD) for May 2011 (Phelps) were assigned to wards using the relevant look-up files supplied by the Office for National Statistics Open Geography Portal. Each code is linked to a grid reference on the National Grid, and these were used to create geographic centroids for each ward using simple averaging of northings and eastings. 
Census wards have been classified according to how urban or rural they are (ONS “Area and Rural-Urban”) and this classification was used to identify those buildings and wards that were outside areas classed as urban conurbations (major conurbation, A1, or minor conurbation, B1). These were classifications 'urban city and town' (C1 and C2), 'rural town and fringe' (D1 and D2) and 'rural village and dispersed' (E1 and E2). In what follows, analyses that excluded urban conurbations excluded both buildings that were in such conurbations, and also wards that were in conurbations but linked to buildings that were not. (This avoided cases where some wards over $12 \mathrm{~km}$ from a non-conurbation building were in a conurbation and nearer to another building in that conurbation). The ward classification of the building to which a ward was linked, and that of the ward itself, were included as controls to allow for the generally higher affiliation to Christianity in rural rather than urban areas.

\section{Buildings}

The buildings included in the dataset were (a) 42 Church of England Cathedrals (all 2011 diocesan cathedrals except St German’s, Peel, cathedral for the Diocese of Sodor \& Man), (b) 19 Roman Catholic cathedrals, and (c) 41 Church of England buildings then belonging to the Greater Churches Network (GCN). The latter network includes some buildings that are as large as, or larger than, many cathedrals and are notable landmarks such as Bath Abbey, Great Malvern Priory, Selby Abbey and Wimborne Minister. Including buildings other than Anglican cathedrals was important in some areas, where people may be some distance from an Anglican Cathedral, but living close to a building that has a similar physical presence. The geography of northern England meant that few if any English wards along the Scottish border were nearer to a large church in Scotland than to one in England. However, along the Welsh border a few wards were nearer to large Welsh churches than large English ones, so churches in Wrexham, Welshpool and Chepstow were also included in the final list of 105 church buildings. 
Buildings were located by using postcodes and looking up the grid references from the NPCD. Using postcodes for this purpose, and for calculating ward centroids, may have introduced some inaccuracies, but they were considered minor and likely to be trivial compared with the variations not related to the spatial separation of wards and buildings. For each ward, the distance to (a) the nearest large church and (b) the nearest Anglican cathedral were calculated using grid references. On average, each building had 72 wards to which it was the nearest building in the dataset, but the actual number ranged from 4 (the Roman Catholic cathedral at Shrewsbury) to 287 (All Saints, Kingston upon Thames). For this analysis, wards more than $30 \mathrm{~km}$ from a building were excluded altogether, leaving 6,712 in the overall sample. To test if the nature of the building influenced the proximity effect, an index of the building size was taken as the product of its length, width and height ${ }^{1}$.

\section{Census 2011 Key Statistics}

Key statistics for wards from the 2011 Census were downloaded from the Office for National Statistics NOMIS webpage (ONS, “Key Statistics”). The ward-level key statistics collected through the National Census include a wide range of socio-demographic information, which was used to create the dependent variable and the control variables.

Dependent variable. The religion question in the 2011 Census asked people to assign themselves as belonging to one of the major religions (options were Christian, Muslim, Hindu, Sikh, Jewish, Buddhist), to another specified religion, to specify no religion, or to opt not to answer the question (ONS "Religion in England and Wales 2011”). The England totals for the religion key statistics ward-data indicated that 59.3\% of 53,012,456 people assigned themselves as Christian, $24.7 \%$ as no religion, and $7.2 \%$ did not state religion. The main effect, if any, of the presence of a large Christian building in England on affiliation is likely to be a shift from non-affiliation to Christian affiliation, so the dependent variable used was 
Christian affiliation as a percentage of those who were Christian, did not affiliate to any other religion or did not state religion. As non-Christian religious affiliates made up only $8.7 \%$ of the population overall, the dependent variable used (referred to here as \%Christians for simplicity) was in most wards very close to the percentage of Christian affiliates in the total sample, but in some wards that were ethnically or religiously diverse, it could diverge by as much as $50 \%$.

Control variables. Large Christian buildings are not randomly distributed in relation to the population, but tend to occur in cities and large towns, and within those places tend to be near the city or town centre. Testing the hypothesis assumes that, 'all other things being equal', there may be a higher percentage of Christian affiliates close to buildings than further away. To try and control statistically for the socio-demographic variability of wards, the following variables were included as controls: population density (per $\mathrm{km}^{2}$ ); \% ethnic group White; \% aged 25-44; \% full time students; \% working in professional or higher managerial occupations; \% with an undergraduate or postgraduate degree; \% with no qualifications; \% economically inactive; \% single; \% in a registered civil partnership; \% Muslim; \% affiliating to religion other than Christianity or Islam. The latter two variables were not directly related to the dependent variable and were included to allow for the possibility that in areas where a national minority religion is dominant, non-affiliating people may be less likely to have Christian roots or connections. All key statistics variables were grand-mean centred.

\section{Analysis}

Adjacent wards are more likely to be demographically similar to one another than those that are further apart. This grouping can be expressed by assuming wards linked to the same building (by virtue of that being their nearest large church) are in the same group, analogous to the way that school pupils are grouped in classes or churchgoers in congregations. 
Hierarchical linear modelling takes into account the lack of independence of grouped cases, and is a more robust way of analysing grouped data than using ordinary least squares multiple regression (Bickel; Snijders and Bosker). It also allows variables at group (context) level to be included in the same hierarchical linear model as variables measured for cases within each group. In this study, ward-level data were treated as being at level one, and building-level data were treated as being at level two in multi-level hierarchical linear models. In these models, \%Christians in each ward was the dependent variable, key statistics and ward ruralness were level-one controls, and building characteristics and building ruralness (i.e., ruralness of the ward it was in) were level-two controls. The analysis used the linear mixed model procedure of IBM SPSS Statistics 20 to define a series of regression models using different subsamples of the English 2011 Census wards:

1. All 6,712 wards in England that were within $30 \mathrm{~km}$ of the 105 buildings in the dataset were included in a series of regression models, using buildings as the group (subject) variable).

Model 0 was the null model with no predictor variables;

Model 1 added distance of ward from the building, where distance was categorized into $>3 \mathrm{~km}$ (reference category), 3-6 km, 7-12 km and 13-30 km;

Model 2 added the key statistics and ruralness of the building and ward as controls;

Model 3 added a level-two variable related to the nature of the building, the building size index.

2. Models $4 \mathrm{a}$ and $4 \mathrm{~b}$ repeated Models 1 and 2 but with the 4,536 wards that were linked to a building that was outside an urban conurbation.

3. Models $5 \mathrm{a}$ and $5 \mathrm{~b}$ repeated Models $4 \mathrm{a}$ and $4 \mathrm{~b}$ but with the 3,476 wards that were linked to a Church of England cathedral that was outside an urban conurbation. 
4. Models $6 \mathrm{a}$ and $6 \mathrm{~b}$ repeated Models $4 \mathrm{a}$ and $4 \mathrm{~b}$ but with the 637 wards that were linked to a Roman Catholic cathedral that was outside an urban conurbation.

\section{Results}

The 6,712 wards in the sample varied enormously on most of the key statistics (Table 1). For example, average population density was 29.8 people per $\mathrm{km}^{2}$ but individual wards ranged from 0.1 to 264.7 people per $\mathrm{km}^{2}$. Christian affiliation averaged $62.3 \%$ but ranged from $8 \%$ to $85 \%$ across wards. The adjusted \%Christians (excluding affiliates of other religions) averaged $66.0 \%$ and ranged from $30 \%$ to $85 \%$, indicating that levels of affiliation below $30 \%$ were likely to be strongly influenced by the presence of other religious groups in a ward. In the overall data, the \%Christians was much lower, on average, in wards near to large churches than those further away, the exact opposite of the main hypothesis (Figure 1). Affiliation increased until around $6 \mathrm{~km}$ from building, and levelled off thereafter. This is likely to represent the fact that most large churches are near the centre of urban areas, where the social demography is very different from suburban or rural areas. Some support for this is shown in Figure 2, where wards are classified according to the urban or rural location of the building to which they are linked. Churches in urban conurbations showed the same pattern of increasing affiliation further from the building, and this was also true to a lesser extent where the building was in an urban town or city. However, in the few cases where the building was in a rural town or village (only 6 of 105 buildings), the trend was in the opposite direction.

[Table 1, Figures $1 \& 2$ about here]

Hierarchical regression for all wards within $30 \mathrm{~km}$ of a large church showed that, without any predictor variables but grouping by building (Model 0), the intraclass correlation 
coefficient (ICC) was 38\%, showing that a relatively large proportion of the variation in \%Christians could be explained by variation between the wards associated with different buildings, rather than variations between wards associated with the same building (Table 2). This is what might be expected given the very different contexts of large church buildings across England and the likelihood that wards in the same area will have similar levels of Christian affiliation. Adding distance from the building (Model 1) reduced some of the residual variance (associated with differences between wards linked to the same building), but made little difference to the intercept variance (variance between wards associated with different buildings), so the ICC increased. The proximity estimates indicated that, compared with wards within $3 \mathrm{~km}$ of a large church, wards 3-6 km away had 4.48\% more Christians, while those $7-12 \mathrm{~km}$ away had 7.54\% more, and those $13-30 \mathrm{~km}$ away $7.37 \%$ more. This confirms the trends seen in Figure 1. However, after controlling for socio-demographic factors (Model 2) the trend was reversed and there was small, but statistically significant, decline in the \%Christians away from larger churches compared with wards within $3 \mathrm{~km}$. The difference was $0.91 \%$ fewer than expected 3-6 km away, 0.40\% fewer 7-12 km away, and 0.81\% fewer 13-30 km away. In other words, after controlling for socio-demographic factors, there was a very slight but discernible effect that wards close to large churches had a slightly higher percentage of Christian affiliates than expected if proximity had no effect. Adding factors associated with the buildings themselves (Model 3) made no significant difference to the model fit, suggesting that it may be something other than the nature or size of the building itself that is influencing any proximity effect.

[Table 2 about here] 
The proximity effect was maintained, and in fact increased, when analysis was restricted to buildings outside urban conurbations (Models 4a and 4b), especially if the buildings were just Anglican cathedrals (Model 5a and 5b). In the latter case, wards 3-6 km from the cathedrals had $1.28 \%$ fewer Christians on average than wards nearer to cathedrals. This was apparent only after controlling for social demography, and even these Anglican cathedrals were actually in wards with fewer Christian affiliates (in absolute terms) than those further away. The 205 wards that were within $3 \mathrm{~km}$ of an Anglican cathedral had an average population of 8,331, so $1.28 \%$ more Christians than expected amounts to about 100 people on average. This is more than might be expected if it was simply due to, say, cathedral staff living in the cathedral precincts or staff of a diocesan office close to a cathedral living nearby.

[Table 3 about here]

For historical reasons, Roman Catholic cathedrals are more likely than Church of England cathedrals to be situated in places where they can serve a particular (i.e., Catholic) population (for example in Liverpool). Running the analysis for just RC cathedrals outside urban conurbations (Models 6a and 6b) showed similar trends to the Anglican cathedrals: without socio-demographic controls, there were 5-7\% fewer Christians within 3km than further away; after adding controls, the trend was reversed. Unlike Anglican cathedrals, for RC cathedrals the decline in expected Christian affiliation continued beyond $6 \mathrm{~km}$ and even beyond $12 \mathrm{~km}$.

\section{Discussion and conclusion}


The spatial analysis of Christian affiliation in relation to the location of large churches has revealed two key findings.

First, far from being set in areas of high Christian affiliation, large churches are mostly in areas that have much lower levels of Christian affiliation than the national average. This seems to be due to the nature of large settlements, which are typified by having low numbers of Christians in city centres where Cathedrals tend to be situated. In the few cases where there are large churches in mainly rural areas, affiliation was often higher, in absolute terms, nearer the building than further away. For most large churches, however, the trend was very much the other way around and they are situated in areas of unusually low Christian affiliation. There may be multiple factors that account for this, and it was not simply a matter of different ethnic or religious groups settling nearer town or city centres. Instead it seemed that the higher proportions of students, more educated people, those in professional occupations, single people and those in civil partnerships all combined to explain why there are fewer than expected Christians close to large buildings. In terms of the mission of these institutions the message seems clear: they need look no further than their doorsteps to find unbelievers. The sorts of people living nearby may not necessarily be the poor and marginalized, but might rather be well-off professionals who may need a ministry that caters to different sorts of spiritual needs to those who mostly attend church.

Second, there is some evidence that comparing like for like (controlling for social demography) there is indeed a trend for higher than expected levels of Christian affiliation nearer to large buildings. The effect is small (in the order of 1\%), and in most cases the difference is between wards within $3 \mathrm{~km}$ and the rest. It is not possible to decide from the Census data exactly why this effect occurs, and it might be purely spurious. However, it seems to hold for all buildings in all sorts of settlements, and especially where cathedrals are the focus building. This implies that it is a phenomenon worth investigating in more detail. 


\section{Interpreting the findings}

The findings reported here are open to several different interpretations, and we are not able to use the Census data to decide between them. For a start, it is not clear what exactly the religion question measures, especially for those who select 'Christian'. It is clearly not simply about practicing Christianity in terms of attendance, and may not necessarily reflect adherence to particular beliefs. It may be, as others have suggested (Voas) that it is largely a matter of identity, which may be national but could also be more specifically religious. However, when the Richard Dawkins Foundation followed the 2011 Census with questions about belief for a representative sample of 1136 adults who had affiliated as Christian, they found over 70\% agreed that Jesus "Came back to life [either spiritually of physically] after being dead” (MORI), and half had attended worship in the previous 12 months. Although

Dawkins interpreted such figures to argue that Christianity is dead in Britain (Hennessy), they actually suggest that for many people Census affiliation may involve more than simple cultural identification.

Whatever the meaning of the increased affiliation near large buildings there remains the issue of cause and effect: do people settle near such buildings because they are affiliated to the same religion, or does living nearby induce such affiliation in people who would otherwise say they are not religious? We think it unlikely that anyone other than staff would elect to settle near a cathedral because they are Christian, and our data show that living near such a building actually means living in a place that is anything but a Christian enclave. There may be an indirect link if houses near Cathedrals tend to be occupied by people of particular social strata that happened to include more Christian affiliates but, again, the direct evidence was in the opposite direction. A causal path could itself have different explanations, which might be related to the action of those who belong to the staff or congregations of the 
building in influencing their neighbours to become Christians. However, in many cathedrals the congregations tend to travel some distance to worship, and the effects we observed may be geographically too close to the buildings to be explained by social networks developed by existing members in their neighbourhoods. This could be tested by more detailed study of where congregations and staff live, and how they relate to areas adjacent to their place of worship.

There remains a possibility that the presence of the building might more directly influence a person's sense of identity, and hence their preferred religious affiliation. Given the suggestion that a good proportion of the Christian affiliates in the Census may have been expressing some sort of identity (rather than active faith), this reason for the proximity effect remains a possibility. Grace Davie’s notion of vicarious religion may offer some explanation here because she argues not just that religious institutions may be understood to "perform" religion on behalf of others, but also that those who are not necessarily religious invest symbolic meaning in church buildings ("Vicarious Religion” 25-6). This tendency could be most evident for people who live near such buildings, if so it might at least partly explain our findings.

Implications for the Church and future research agenda

Whatever the reasons for the building proximity effect (Muskett), it is likely to be related to how cathedrals and the other prominent churches live out their "particular way of being the Church” (Platten and Lewis 178). In a changing religious context (Woodhead and Catto), the future of the Church may well be "informed by the ecclesiology, lived out in cathedrals" as Platten and Lewis claimed (178). Just as the analysis here has revealed that the influence of cathedrals and cathedral-like church buildings is not related to the nature of the building (length and/or height) per se, so too Platten and Lewis (178) argued that "the distinctiveness 
of ... cathedral ecclesiology is not dependent on great size, age or beauty”. Instead, they said it depends on "a cathedral being a special, open, transcendent building which is the bishop's seat, and on its having obligations which force the life of the place to be outward-looking, even when the pressure of the age encourage religious (and secular) introversion” (178-9). The most fruitful guide to setting the course for the flagships was said to be the theology of incarnation, emphasizing commitment to local context (179). This should avoid casting shadows that marginalize (Minton) or simply discomfort (as in D.H. Lawrence’s The Rainbow, to which Platten \& Lewis, 1998 drew attention).

If the influence of big church buildings on self-identified Christian affiliation is not associated directly with their size and shape, and their future ecclesiology is equally not dependent on their physical features, it may be that their impact derives partly from their role in offering real and virtual space for the "vicarious debate of unresolved issues in modern societies" (see the variety of ways that religion can operate vicariously in Davie, "Vicarious Religion” 22-23). Interestingly, Shaw has noted that, when Rowan Williams the then Archbishop of Canterbury launched the Spiritual Capital report in 2012 (Theos and The Grubb Institute), he said that a cathedral is "a stage on which the most important issues can be framed and explored" (see Thornton).

The present investigation used the rather blunt instrument of Census data aggregated by wards. Distance from the building relied on geographic centroids rather than population centroids, which are now available for some lower-level geographies (ONS An Overview of Best-Fitting). Future work could refine the approach by using data from different output areas, using a wider range of buildings, and defining locations more precisely. These steps might test the robustness of the trend, but they would not help to explain it. Explanation would require closer examination of Christians who live near large churches to explore 
whether affiliation is linked to attendance at the church and whether changes in affiliation are related to moving nearer to a building.

\section{NOTE}

${ }^{1}$ Length, width and height were taken from cathedral/church websites, or Cook's volume on cathedrals, or the range of county volumes in The Buildings of England series by Pevsner (and co-authors). In the rare cases where dimensions were not available from those sources, approximations were made using satellite imagery. 


\section{REFERENCES}

Anderson, Andrew. "Building and Cherishing. Cathedrals as Buildings.” Flagships of the Spirit. Cathedrals in Society. Eds. Stephen Platten and Christopher Lewis. London: Darton, Longman and Todd, 1998. 90-104.

Bickel, Robert. Multilevel Analysis for Applied Research: It’s Just Regression! New York: Guildford Press, 2007.

Cook, G. H. The English Cathedral through the Centuries. London: Phoenix House, 1957. Danziger, Danny. The Cathedral. Behind Open Doors - Talking with People Who Give Their Lives to a Cathedral. London: Viking, 1989.

Davie, Grace “Vicarious Religion: A Methodological Challenge.” Everyday Religion: Observing Modern Religious Lives. Ed. Nancy T. Ammerman. New York: Oxford University Press, 2007. 21-35.

Day, Abby. Believing in Belonging: Belief and Social Identity in the Modern World. Oxford: Oxford University Press, 2011.

GCN. “Greater Churches Network”. Web. 8 Jan. 2015. <http://greaterchurches.org/>. IBM_Corporation. IBM SPSS Advanced Statistics 20. Chicago, IL: IBM Corporation, 2011. Martikainen, Tuomas. "Consuming a Cathedral: Commodifcation of Religious Places in Late Modernity.” Fieldwork in Religion 2.2 (2006): 127-45.

Minton, Thomas D. "In the Shadow of Cathedrals: A Case Study of Marginality Created by ‘Cathedral Culture’ in Basel, Switzerland.” Missiology: An International Review 26.1 (1998): 67-85.

Muskett, Judith A. "Reflections on the Shop Windows of the Church of England: Anglican Cathedrals and Vicarious Religion.” Journal of Contemporary Religion 30.2 (2015): 273-289.

Office for National Statistics. Focus on Religion. London: HMSO, 2004. 
---.. “Religion in England and Wales 2011”. London, 2012. Web. 8 Jan. 2015. <http://www.ons.gov.uk/ons/dcp171776_290510.pdf>.

---.. “Area and Rural-Urban Classifications”. London, 2014. Web. 8 Jan. 2015. $<$ http://www.ons.gov.uk/ons/guide-method/geography/products/areaclassifications/index.html>.

---. “Key Statistics 2011 Census Bulk Download (Release 2)”. London, 2012. Web. 8 Jan. 2015. <http://www.nomisweb.co.uk/census/2011/bulk/r2_2\#KeyStatistics>.

---. “Open Geography Portal”. London, 2014. Web. 8 Jan. 2015.

<https://geoportal.statistics.gov.uk/geoportal/catalog/main/home.page>.

---. An Overview of Best-Fitting: Building 2011 Census Estimates from Output Areas.

London: Office for National Statistics, 2012.

Phelps, Mike. ONS Postcode Directory User Guide. London: Office for National Statistics, 2011.

Platten, Stephen, and Christopher Lewis, eds. Flagships of the Spirit: Cathedrals in Society. London: Darton, Longman and Todd, 1998.

Shaw, Jane. “The Potential of Cathedrals.” Anglican Theological Review 95.1 (2013): 13747.

Shearlock, David. "Cathedrals and the Musical Tradition.” Cathedrals Now: Their Use and Place in Society. Ed. Iain M. MacKenzie. Norwich: Canterbury Press, 1996. 9-23.

Snijders, Tom A. B., and Roel J. Bosker. Multilevel Analysis: An Introduction to Basic and Advanced Multilevel Modeling. London: Sage, 1999.

Theos and The Grubb Institute. Spiritual Capital: The Present and Future of English Cathedrals. A Research Report Commissioned by the Foundation for Church Leadership and the Association of English Cathedrals. London, 2012.

Thornton, Ed. “Cathedrals ‘Appeal to Non-Religious’.” The Church Times. 19 Oct. 2012. 
Tilby, Angela. “The Sacred Grove.” Flagships of the Spirit. Cathedrals in Society. Eds. Stephen Platten, and Christopher Lewis. London: Darton, Longman and Todd, 1998. $155-70$.

Voas, David, and Siobhan McAndrew. “Three Puzzles of Non-Religion in Britain.” Journal of Contemporary Religion 27.1 (2012): 29-48.

Walpole, Hugh. "Foreword”. The Cathedrals of England. Harry Batsford, and Charles Fry. London: B.T. Batsford, 1934.

Weller, Paul. "Identity, Politics, and the Future(s) of Religion in the UK: The Case of the Religion Questions in the 2001 Decennial Census.” Journal of Contemporary Religion 19.1 (2004): 3-21.

Wharton, Annabel Jane. Architectural Agents. The Delusional, Abusive, Addictive Lives of Buildings. Minneapolis: University of Minnesota Press, 2015.

Woodhead, Linda, and Rebecca Catto, eds. Religion and Change in Modern Britain. Abingdon: Routledge, 2012. 
Table 1. Key statistics for the 6,712 English 2011 Census wards that were within $30 \mathrm{~km}$ of a large church building.

\begin{tabular}{|c|c|c|c|c|}
\hline & Mean & SD & Min. & Max. \\
\hline Population density $\left(/ \mathrm{km}^{2}\right)$ & 29.8 & 0.5 & 0.1 & 264.7 \\
\hline$\%$ ethnically White & 85.5 & 18.1 & 4 & 99 \\
\hline$\%$ aged $25-44$ & 25.9 & 6.1 & 2 & 64 \\
\hline$\%$ full time students & 7.8 & 6.4 & 2 & 95 \\
\hline$\%$ professionals & 11.0 & 5.3 & 1 & 43 \\
\hline$\%$ with degree & 27.8 & 10.7 & 5 & 78 \\
\hline$\%$ with no qualifications & 22.0 & 7.3 & 1 & 49 \\
\hline$\%$ economically inactive & 33.6 & 6.5 & 11 & 85 \\
\hline \% single & 31.7 & 9.9 & 13 & 96 \\
\hline$\%$ in registered civil partnership & 0.2 & 0.2 & 0 & 4 \\
\hline \% Christian (whole sample) & 62.3 & 10.2 & 8 & 85 \\
\hline $\begin{array}{l}\% \text { Christians (excluding other } \\
\text { affiliates) }\end{array}$ & 66.0 & 7.1 & 30 & 85 \\
\hline$\%$ no religion & 24.7 & 6.5 & 1 & 56 \\
\hline$\%$ religion not specified & 7.2 & 1.4 & 3 & 26 \\
\hline \% Muslim & 3.1 & 7.5 & 0 & 85 \\
\hline$\%$ affiliates of other religions ${ }^{*}$ & 5.8 & 10.5 & 0 & 86 \\
\hline
\end{tabular}

Note. ${ }^{*}$ This is the percentage of those who religiously affiliated to a religion other than Christianity or Islam. 
Table 2. Hierarchical linear regression of \%Christians for 6,712 English 2011 Census wards that were within 30 km of a large church building.

\begin{tabular}{|c|c|c|c|c|c|}
\hline & & Model 0 & Model 1 & Model 2 & Model 3 \\
\hline Intercept & & $65.97(0.45)^{* * *}$ & $59.96(0.49)^{* * *}$ & $66.54(1.73)^{* * *}$ & $66.65(1.93)^{* * *}$ \\
\hline Distance from building & $13-30 \mathrm{~km}$ & & $7.37(0.25)^{* * *}$ & $-0.81(0.18)^{* *}$ & $-0.81(0.18)^{* *}$ \\
\hline$($ ref $<3 \mathrm{~km})$ & $7-12$ km & & $7.54(0.27)^{* * *}$ & $-0.40(0.18)^{*}$ & $-0.40(0.18)^{*}$ \\
\hline & 3-6 km & & $4.48(0.28)^{* * *}$ & $-0.91(0.18)^{* *}$ & $-0.91(0.18)^{* *}$ \\
\hline Population density & & & & $-0.01(0.00)^{* * *}$ & $-0.01(0.00)^{* * *}$ \\
\hline \% White & & & & $-0.32(0.01)^{* * *}$ & $-0.32(0.01)^{* * *}$ \\
\hline$\%$ aged $25-44$ & & & & $-0.21(0.02)^{* * *}$ & $-0.21(0.02)^{* * *}$ \\
\hline$\%$ full-time students & & & & $0.12(0.02)^{* * *}$ & $0.12(0.02)^{* * *}$ \\
\hline$\%$ professionals & & & & $0.13(0.03)^{* *}$ & $0.13(0.03)^{* *}$ \\
\hline$\%$ with degree & & & & $-0.21(0.02)^{* * *}$ & $-0.21(0.02)^{* * *}$ \\
\hline$\%$ with no qualifications & & & & $-0.03(0.02)$ & $-0.03(0.02)$ \\
\hline$\%$ economically inactive & & & & $-0.14(0.02)^{* * *}$ & $-0.14(0.02)^{* * *}$ \\
\hline$\%$ single & & & & $-0.58(0.02)^{* * *}$ & $-0.58(0.02)^{* * *}$ \\
\hline \% in Civil Partnership & & & & $-2.23(0.27)^{* * *}$ & $-2.23(0.27)^{* * *}$ \\
\hline \% Muslims & & & & $-0.12(0.01)^{* * *}$ & $-0.12(0.01)^{* * *}$ \\
\hline$\%$ other religions & & & & $-0.27(0.01)^{* * *}$ & $-0.27(0.01)^{* * *}$ \\
\hline Building ruralness & Rural & & & $2.53(1.89)$ & $2.46(1.99)$ \\
\hline (ref $=$ Urban conurbation) & Urban town & & & $-0.05(1.79)$ & $-0.07(1.84)$ \\
\hline Ward Ruralness & Rural & & & $-0.22(0.19)$ & $-0.22(0.19)$ \\
\hline (ref = Urban conurbation) & Urban town & & & $-1.40(0.12)^{* * *}$ & $-1.40(0.12)^{* * *}$ \\
\hline Building size index $\left(\mathrm{x} 10^{6}\right)$ & & & & & $0.09(10.09)$ \\
\hline -2 Log Likelihood & & 42777 & 41791 & 34959 & 34977 \\
\hline Deviance & & & $985.57^{* * *}$ & & -18.06 \\
\hline Degrees of freedom & & 2 & 5 & 17 & 22 \\
\hline Residual & & $32.52(0.57)^{* * *}$ & $28.03(0.49)^{* * *}$ & $9.88(0.17)^{* * *}$ & $9.88(0.17)^{* * *}$ \\
\hline Intercept & & $20.07(2.97)^{* * *}$ & $19.51(2.85)^{* * *}$ & $16.98(2.42)^{* * *}$ & $17.50(2.53)^{* * *}$ \\
\hline ICC & & $38 \%$ & $41 \%$ & $63 \%$ & $64 \%$ \\
\hline
\end{tabular}


Note. ICC $=$ intraclass correlation coefficient. ${ }^{*} p<.05 ;{ }^{* *} p<.01 ;{ }^{* * *} p<.001$. Estimated effects and $S D$ in parentheses. 
Table 3. Hierarchical linear regression of \%Christians in wards linked to buildings outside urban conurbations.

\begin{tabular}{|c|c|c|c|c|c|c|c|}
\hline & & \multicolumn{2}{|c|}{ All buildings (4536 wards) } & \multicolumn{2}{|c|}{ Anglican cathedrals (3476 wards) } & \multicolumn{2}{|c|}{ RC Cathedrals (637 wards) } \\
\hline & & Model 4a & Model 4b & Model 5a & Model 5b & Model 6a & Model 6b \\
\hline Intercept & & $60.88(0.54)^{* * *}$ & $66.08(1.57)^{* * *}$ & $59.31(0.63)^{* * *}$ & $67.52(1.84)^{* * *}$ & $58.83(1.74)^{* * *}$ & $64.01(5.13)^{* * *}$ \\
\hline \multirow{3}{*}{$\begin{array}{l}\text { Distance from building } \\
\text { (ref }<3 \mathrm{~km})\end{array}$} & $13-30 \mathrm{~km}$ & $6.19(0.28)^{* * *}$ & $-1.12(0.17)^{* * *}$ & $7.64(0.36)^{* * *}$ & $-0.96(0.23)^{* * *}$ & $6.11(0.93)^{* * *}$ & $-3.51(0.52)^{* * *}$ \\
\hline & $7-12$ km & $6.83(0.31)^{* * *}$ & $-0.83(0.19)^{* * *}$ & $8.15(0.40)^{* * *}$ & $-0.71(0.25)^{* *}$ & $7.44(1.02)^{* * *}$ & $-2.87(0.55)^{* * *}$ \\
\hline & 3-6 km & $4.80(0.33)^{* * *}$ & $-0.96(0.19)^{* * *}$ & $5.53(0.43)^{* * *}$ & $-1.28(0.26)^{* * *}$ & $5.69(1.05)^{* * *}$ & $-1.55(0.53)^{* *}$ \\
\hline Population density & & & $-0.02(0.00)^{* * *}$ & & $-0.02(0.00)^{* * *}$ & & $0.00(0.01)$ \\
\hline$\%$ white & & & $-0.29(0.01)^{* * *}$ & & $-0.31(0.02)^{* * *}$ & & $-0.16(0.05)^{* *}$ \\
\hline$\%$ aged $25-44$ & & & $-0.29(0.02)^{* * *}$ & & $-0.30(0.03)^{* * *}$ & & $-0.23(0.06)^{* * *}$ \\
\hline$\%$ full-time students & & & $0.07(0.02)^{* * *}$ & & $0.05(0.02)^{*}$ & & $0.03(0.06)$ \\
\hline$\%$ professionals & & & $0.15(0.04)^{* * *}$ & & $0.14(0.04)^{* *}$ & & $0.36(0.10)^{* *}$ \\
\hline$\%$ with degree & & & $-0.21(0.02)^{* * *}$ & & $-0.20(0.02)^{* * *}$ & & $-0.28(0.06)^{* * *}$ \\
\hline$\%$ with no qualifications & & & $-0.08(0.02)^{* * *}$ & & $-0.09(0.02)^{* * *}$ & & $-0.12(0.06)^{*}$ \\
\hline$\%$ economically inactive & & & $-0.14(0.02)^{* * *}$ & & $-0.12(0.02)^{* * *}$ & & $-0.05(0.04)$ \\
\hline$\%$ single & & & $-0.52(0.02)^{* * *}$ & & $-0.50(0.02)^{* * *}$ & & $-0.54(0.05)^{* * *}$ \\
\hline \% in Civil Partnership & & & $-2.02(0.32)^{* * *}$ & & $-1.96(0.39)^{* * *}$ & & $-1.79(0.80)^{*}$ \\
\hline \% Muslims & & & $-0.01(0.02)$ & & $-0.03(0.02)$ & & $0.03(0.14)$ \\
\hline$\%$ other religions & & & $-0.35(0.02)^{* * *}$ & & $-0.35(0.03)^{* * *}$ & & $-0.21(0.15)$ \\
\hline Building ruralness (Urban town) & Rural & & $-0.08(1.62)$ & & $-0.13(1.89)$ & & $2.95(5.38)$ \\
\hline Ward Ruralness (Urban town) & Rural & & $-0.80(0.12)^{* * *}$ & & $-0.80(0.13)^{* * *}$ & & $-1.01(0.34)^{* * *}$ \\
\hline -2 Log Likelihood & & 27941 & 22377 & 21255 & 17153 & 4153 & 3215 \\
\hline Deviance & & & $5564^{* * *}$ & & $4101^{* * *}$ & & $937^{* * *}$ \\
\hline Degrees of freedom & & 5 & 19 & 5 & 19 & 5 & 19 \\
\hline Residual & & $26.18(0.49)^{* * *}$ & $7.43(0.16)^{* * *}$ & $24.86(0.60)^{* * *}$ & $7.35(0.18)^{* * *}$ & $38.29(2.17)^{* * *}$ & $8.06(0.46)^{* * *}$ \\
\hline Intercept & & $16.90(2.81)^{* * *}$ & $14.08(2.36)^{* * *}$ & $18.40(3.44)^{* * *}$ & $15.97(2.85)^{* * *}$ & $23.05(11.57)^{*}$ & $25.83(13.04)^{*}$ \\
\hline ICC & & $39 \%$ & $65 \%$ & $43 \%$ & $68 \%$ & $38 \%$ & $76 \%$ \\
\hline
\end{tabular}


Note. See Table 2. 
Figure 1. Mean \%Christians in wards up to $30 \mathrm{~km}$ from a large church building.

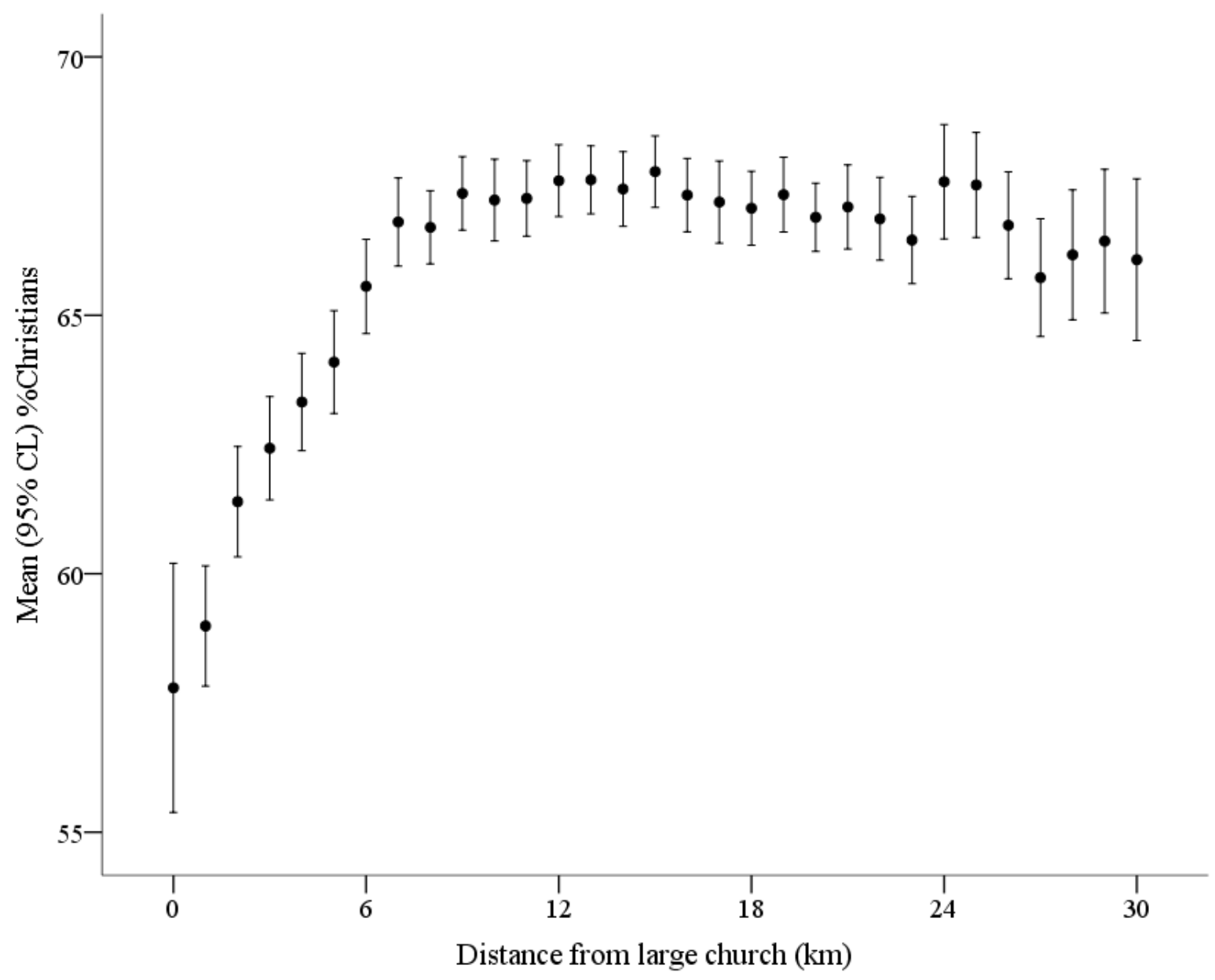


Figure 2. Mean \%Christians in wards classed as urban conurbation (solid circles), urban town or city (open circles) or rural town or village (open squares) at varying distances from a large church building.

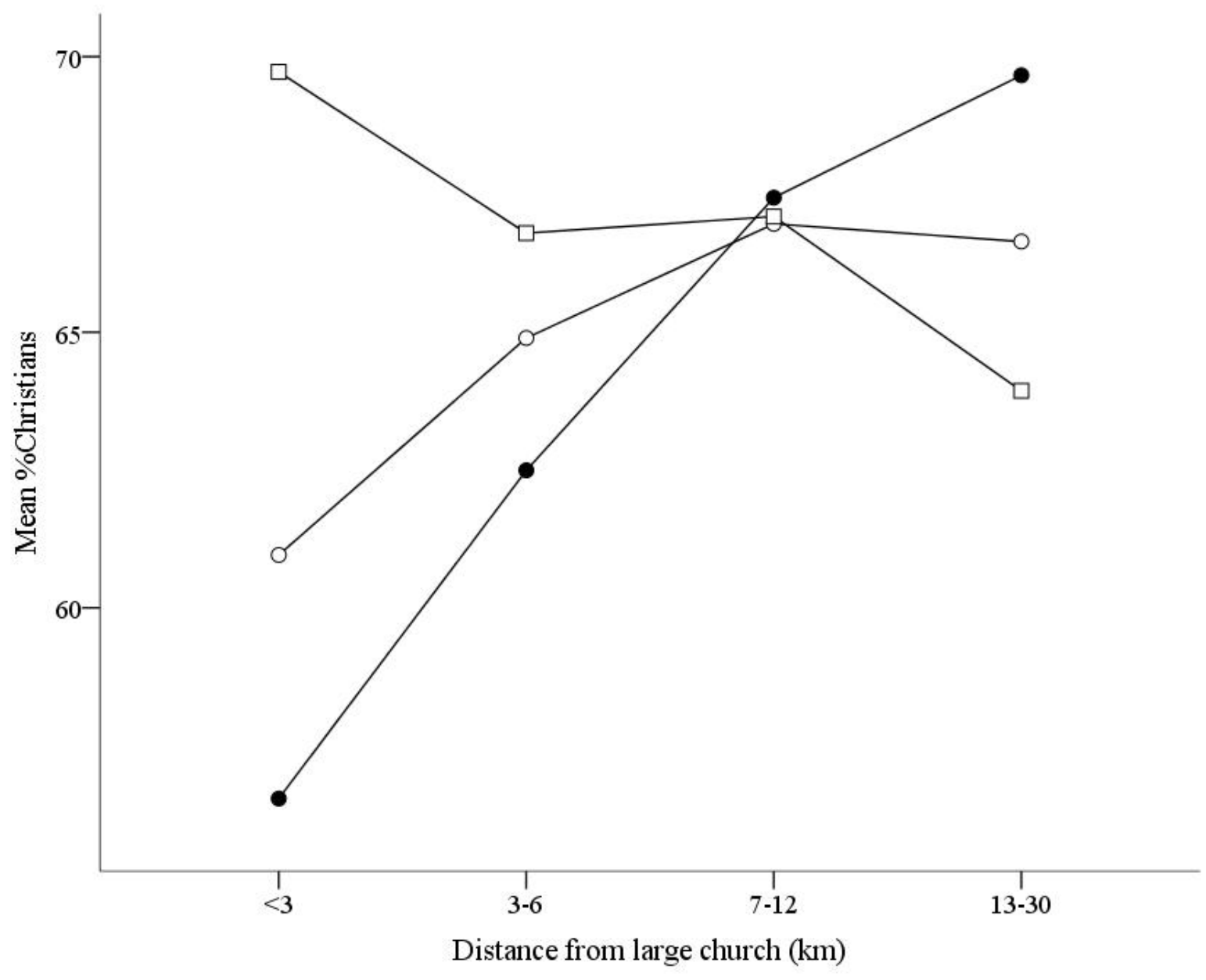

